\section{Comparative Study of Dutch and Hungarian Environmentally-friendly Apple Orchards on Potential Ascospore Dose of Apple Scab}

\author{
Imre Holb $^{1}$ - Bart Heijne ${ }^{2}$ \\ ${ }^{1}$ University of Debrecen, Centre of Agricultural Sciences, \\ Faculty of Agricultural Sciences, \\ Department of Plant Protection, Debrecen \\ ${ }^{2}$ Wageningen University and Research Centre, \\ Applied Plant Research, Zetten-The Netherlands
}

\begin{abstract}
SUMMARY
In a 2-year study, Dutch and Hungarian environmentallyfriendly apple orchards were compared as regards the amount of apple scab primary inoculum. The PAD (potential ascospore dose) method was used to quantify the potential amount of primary inoculum (ascospores) per $\mathrm{m}^{2}$ orchard floor. Applying this method, the number of lesions per $\mathrm{m}^{2}$ of leaf in the autumn (LD), the proportion of the orchard floor covered by leaf litter at bud break (LLD) and potential ascospore dose (PAD) were determined. In autumn, LD values ranged between 2.2 and 13.5 in the integrated orchards, while in the organic orchards the values were between 42.5 and 106.2, with especially high values in the Dutch organic orchard. LLD values ranged between 24 and $43 \%$ at bud break in both countries. PAD values were 10-60 times higher than those of the integrated orchards. The $P A D$ values were between 673 and 4275 ascospore $/ \mathrm{m}^{2}$ orchard floor in the integrated orchards, while in the organic orchards these values were 37102 and 52390 ascospore $/ \mathrm{m}^{2}$ orchard floor, respectively. On the basis of the recorded primary inoculum quantity, the Dutch integrated apple orchard is considered to be excellently protected, while the Hungarian orchard has a medium level of protection. However, both countries' organic orchards can be regarded overall as being very poorly protected. Accordingly, in the integrated orchards the predicted epidemic risk is low or medium, while in the organic orchards it is very high on the basis of PAD values.
\end{abstract}

\section{INTRODUCTION}

The apple scab, caused by Venturia inaequalis (Cooke) G. Wint., overwinters as pseudothecia in the infected apple leaf litter. The overwintered pseudothecia begin to develop from the end of February. After a few weeks in early spring, pseudothecium matures and produces ascospores. Ascospores begin to discharge from pseudothecia when they are moistened by rain or heavy dew. Ascospores are dispersed mainly by wind to susceptible young green tissues of the tree where infection occurs. Infection is highly influenced by the susceptibility of the cultivar, weather conditions and the quantity of primary inoculum (ascospore). How these factors interact with ascospore production, discharge and infection under the local conditions of an orchard is critical to know in order to make proper plant protection decisions.

The most frequently detected phase of apple scab life cycle in Hungary is the time when infection occurs according to Mills' infection criteria (Mills and LaPlante, 1951). Less energy and time are devoted in domestic orchards specifying the time when ascospores discharge, although the methods for identifying the maturity of pseudothecia (Surján, 1974) and using small suction spore collectors (Sallai, 1985) are widely known. Unfortunately, in Hungary, the quantitative assessment of scab ascospores is rarely used, although it is proved that there exists a strong correlation between the amount of ascospores and the length as well as the intensity of the primary infection period (MacHardy, 1996). In many countries, several methods are used for measuring and assessing the quantity of accumulated ascospores in orchards. Such methods are the different spore traps operated in the primary infection period (Hirst, 1952; Gadoury and MacHardy, 1983) or the so-called day-degree models (Gadoury and MacHardy, 1982; Rossi et al., 2000) and the method for determining the potential ascospore dose (PAD) (Gadoury and MacHardy, 1986). In the last decades, more emphasis has been lain on the day-degree models by incorporating them into scab warning simulation models (Seem, 1986) and on the PAD in order to integrate control measures for the management of primary apple scab (MacHardy and Jeger, 1983; MacHardy et al., 1993). Presently, the $\mathrm{PAD}$ technique is the most frequently used method in Western countries for assessing and comparing the actual ascospore dose of apple scab in apple orchards in order to predict the danger of epidemic in early spring (Scheer van der, 1993; MacHardy and Sutton, 1997; Stensvand and Amundsen, 1997).

The aims of this paper were: (i) to determine potential ascospore dose in domestic and Dutch environmentally-friendly (integrated and organic) apple orchards (ii) to compare the orchards of two countries on the basis of the PAD method and data of weather observations.

\section{MATERIALS AND METHODS}

\section{Orchard site and spraying}

In Hungary, experiments were carried out in a 1 ha apple orchard with 40 cultivars at Debrecen Fruit Experimental Station, University of Debrecen. The orchard was established in the spring of 1997, using grafted on M26 rootstocks at a spacing of $4 \times 1.5 \mathrm{~m}$. Cultivars were planted in plots. Each plot consisted of 7 trees per cultivar. Plots were placed in a randomised block design with 6 replicates. From the 
first year on, one half of the orchard has been treated according to the Integrated Fruit Production guidelines (Anonymous, 1995), and the other half according to the Organic Fruit Production guidelines (Anonymous, 1997). The cultivars are: resistant: Resi, Remo, Retina, Rewena, Reanda, Releika, Reglindis, Renora, Relinda, Reka, Faw-7262 and Liberty; tolerant: Pilot, Pinova and Piros; current: Jonagold, Jonica, Elstar, Red Elstar, Idared, Royal Gala, Mutsu and Granny Smith; traditional: Red Astrachan, Egri piros, Nyári fontos, Winter Gold Pearmain, Winter Banana, Calville Blanc d'Hiver, Téli piros pogácsa, Fertődi téli, Húsvéti rozmaring, Mosolygós batul, Batul, Darusóvári, Gravenstein, Francia renet, Parker's Pippin and London Pippin.

In the Netherlands, examinations were carried out at Randwijk in two experimental orchards of Wageningen University, Institute of Applied Plant Research. Orchard one has been treated according to the principles of the Dutch Integrated Fruit Production (Mbt) and orchard two according to the principles of the Dutch Organic Fruit Production (SKAL). Regulations of disease and pest control have been renewed annually in both production systems. Spray schedules have been applied since 1996 (year of settlement), in both experimental orchards. The two orchards are separated by a $6 \mathrm{~m}$ wide bitumin road and 2 rows of Alnus cordata hedge. Both orchards consisted of 32 rows. Two rows of cultivar Jonagold alternated with two rows of cultivar Schone van Boskoop in the organic field, and with two rows of cultivar Elstar in the integrated field. All trees were planted at a spacing of $3 \times 1.25$ and grafted on M9 rootstocks.

In both organic orchards at Randwijk and at Debrecen, disease control was based on the regular use of copper and sulphur agent approved in organic production. In the integrated orchards, all the applied chemicals were contact or systemic fungicides from the „green" and the „yellow” list. Disease sprayings were applied in accordance with the criteria of Mills and LaPlante (1951).

\section{Survey on the role of weather}

The role of weather in the development of epidemics and in the changes of PAD values were evaluated by determining the Mills' infection periods from 1 April until 15 October. For this, a HP 100 (G. Lufft Mess- und Regeltechnik Gmbh, Germany) disease warning system was used in Hungary from 1998-2000. In the Netherlands, the duration of leaf wetness was registered with an Omnidata ES 460 (Techno Co. Ltd. Apfeldoorn, the Netherlands) in 1999 and 2000. Afterwards, the „Mety 2.0" scab warning system was utilised to determine the Mills' infection periods.

\section{Quantity of primary inoculum}

The assessment and calculation of the potential quantity of primary inoculum in the experimental orchards was based on the PAD method developed by Gadoury and MacHardy (1986). Accordingly, we applied the next PAD formula adapted to the local conditions of the survey:

\section{$\mathrm{PAD}=\mathrm{LD} \times \mathrm{LLD} \times \mathrm{PD} \times \mathrm{AD} \times \mathrm{n}$}

$\mathrm{PAD}=$ potencial ascospore dose (estimated production of ascospores per $\mathrm{m}^{2}$ orchard floor);

$\mathrm{LD}=$ lesion density (number of lesions per $\mathrm{m}^{2}$ of leaf at leaf fall);

LLD = leaf litter density (the proportion of the orchard floor covered by leaf litter at bud break);

$\mathrm{PD}=$ pseudothecial density (number of pseudothecia per visible lesion), this normally has to be multiplied by lesion fertility factor ( $\mathrm{f}$ );

$\mathrm{AD}=$ Ascal density (number of asci per pseudothecium);

$\mathrm{n}=$ number of ascospores per ascus.

At the end of October in 1997, 1998 and 1999 at Debrecen and in 1998 and 1999 at Randwijk we recorded the number of scab lesions per $\mathrm{m}^{2}$ of leaf at leaf fall (LD). At bud break leaf litter density (LLD) was determined in 1998, 1999 and 2000 at DebrecenPallag and in 1999 and 2000 in Randwijk. Observations were carried out in 4 replicates by examining 200 randomly chosen leaves per replicate. The proportion of fertile lesions varies with the number of lesions per leaf, therefore, it was adjusted according to the measurements of Gadoury and MacHardy (1986). For PAD calculation the fertility index (f), pseudothecial density (PD) and ascal density (AD) were set to $0.025-0.045,23.4$ and 122.8 , respectively in the integrated orchards. In the same order $\mathrm{f}, \mathrm{PD}$, and $\mathrm{AD}$ were $0.025-0.045,46.5$ and 124.1 in organic orchards. PAD and the five density factors were calculated as the average of all cultivars in Hungary, and as the average of cv. Jonagold and cv. Schone van Boscoop in the Dutch organic and of cv. Jonagold and cv. Elstar in the Dutch integrated orchard.

After calculating PAD, the orchards were classified into three groups: well-managed, moderately-managed and poorly-managed according to MacHardy and Sutton (1997). The categories for the effectiveness of disease managements were: $\mathrm{PAD}<600 ; 1000-5000$ and $>5000$, respectively. In accordance with these, the danger of epidemic was considered small in the well-managed, medium in the moderately-managed and high in the poorly-managed orchard.

\section{Statistical analysis}

All data were subjected to analysis of variance (ANOVA) at $\mathrm{P}<0.05$ using the Genstat 5 Release 4.1 statistical package. The significant differences between the two production systems and within the two production systems were evaluated for the density factors of LD, LLD and PAD. 


\section{RESULTS}

\section{Weather conditions}

\section{Debrecen-Pallag}

A total of 39 and 40 infection periods were recorded from 1 April - 15 October in 1998 and 1999, respectively. The Mills infection periods were heavy in 14 and 19 instances, moderate in 16 and 15 instances and low in 9 and 6 instances in 1998 and 1999, respectively (Figure 1). Weather in 1998 and 1999 was favourable for the scab epidemic in Hungary.

Figure 1: The number of Mills' infection periods and distribution of infection by intensity (light, moderate and severe) between 1 April and 15 October at Debrecen

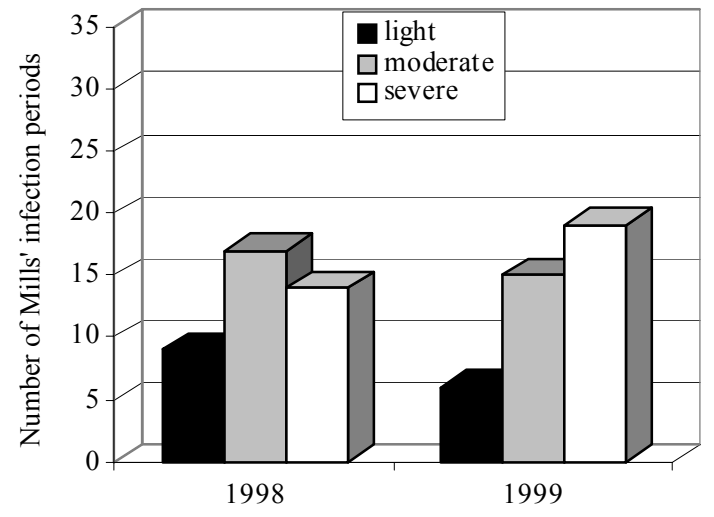

Randwijk

A total of 59 and 58 infection periods were recorded from 1 April - 15 October in 1998 and 1999. In 1998, the Mills' infection periods indicated a possibility of heavy infection in 16 instances, of moderate infection in 23 instances and of low infection in 20 instances (Figure 2). In 1999, the numbers were 33, 8 and 17, respectively (Figure 2). On the basis of these figures, weather conditions were very favorable for the development of a heavy scab epidemic in both years.

Figure 2: The number of Mills' infection periods and distribution of infection by intensity (light, moderate and severe) between 1 April and 15 October at Randwijk

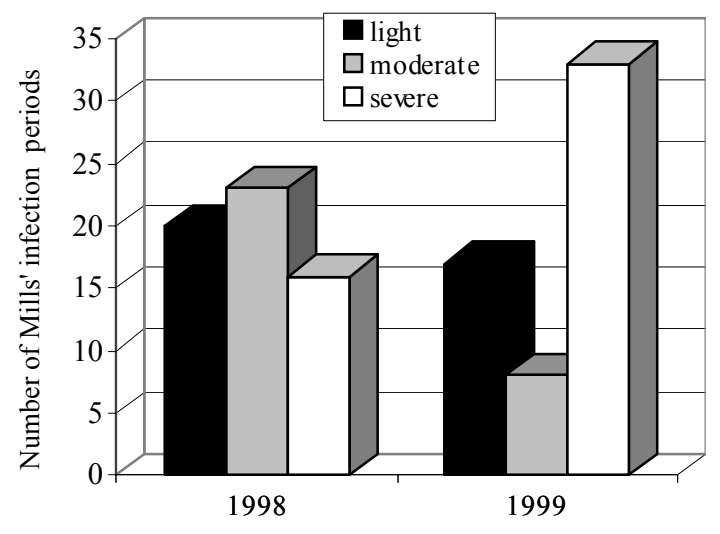

\section{Quantity of primary inoculum}

Debrecen-Pallag

In the organic orchard, the lesion density (LD) was 42.5 and 45.7 lesions $/ \mathrm{m}^{2}$ of leaf area in the end of October in 1998 and 1999, resp. In the integrated orchard these values were 11.5 and 13.5 lesions $/ \mathrm{m}^{2}$ of leaf area, respectively (Figure 3).

At bud break, leaf litter density values (LLD) in $\%$ were approximately equal (41-43\%) in both production systems at Debrecen-Pallag (Figure 4).

At Debrecen-Pallag, the PAD values were 3062 ascospores $/ \mathrm{m}^{2}$ in 1999 , and 4275 in 2000 in the integrated orchard. The estimated production of ascospores per $\mathrm{m}^{2}$ orchard floor was 10 times higher in the organic orchard in each year at DebrecenPallag (Figure 5).

\section{Randwijk}

The lesion density (LD) was 2.2 and 2.3 lesions $/ \mathrm{m}^{2}$ of leaf area in the integrated orchard and was 79.4 and 97.5 lesion $/ \mathrm{m}^{2}$ of leaf area in the organic system in the autumn of 1998 and 1999, respectively. The relatively low lesion density in the Dutch integrated orchard and the very high lesion density in the Dutch organic orchard showed significant differences compared to the Hungarian integrated and organic orchard, respectively (Figure 3).

The leaf litter density values (LLD) in \% ranged between 24 and $36 \%$ at bud break in the Dutch orchards (Figure 4). In the integrated orchard, the ratio of overwintered leaves was $32-36 \%$, while in the organic orchard this was $24-26 \%$. The values of the organic orchard were significantly lower than those measured in the Hungarian organic orchard.

The estimated production of ascospores per $\mathrm{m}^{2}$ orchard floor (PAD) in early spring was the lowest in the Dutch integrated orchard (under 900 ascospores $/ \mathrm{m}^{2}$ in both years). On the other hand, PAD values were about 50-60 times higher in the Dutch organic orchard compared to the Dutch integrated orchard (Figure 5).

\section{Orchard classification}

The number of ascospores per $\mathrm{m}^{2}$ soil surface (PAD) was significantly lower in the integrated orchard than in the organic one in both countries. When comparing the two systems, PAD values were often 10-60 times higher in the organic systems than in the integrated orchards.

The comparison of PAD values according to criteria of MacHardy and Sutton (1997) indicated that the Dutch integrated orchard is well-managed, while the Hungarian one is moderately-managed. However, both counries' organic orchards were considered very poorly-managed in the investigated years. In compliance with these, the predicted risk of epidemic was low and medium in the integrated orchards, while it was very high in the organic orchards on the basis of PAD. 
Figure 3: Lesion density (the number of scab lesions per $\mathbf{m}^{2}$ of leaf at leaf fall) in the integrated and organic apple orchards in 1998 and 1999

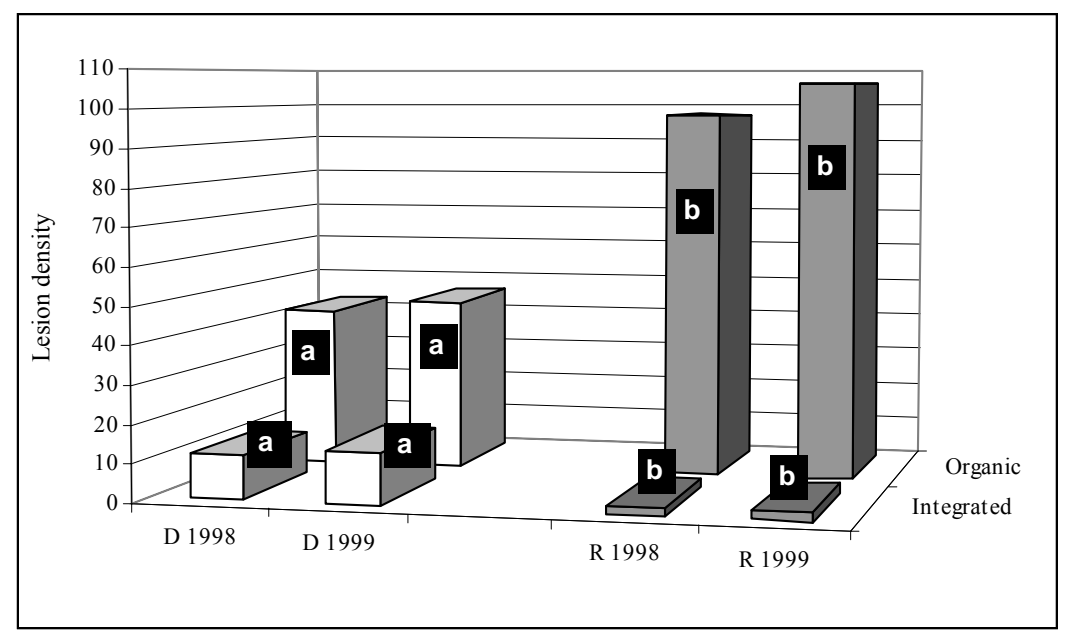

The bold letters on the columns sign the significant differences within the given plant protection system at $\mathrm{P}<0.05$.

$\mathrm{D}=$ Debrecen, Hungary; $\mathrm{R}=$ Randwijk, The Netherlands.

Figure 4: Leaf litter density (the proportion of the orchard floor covered by leaf litter at bud break) in $\%$ in integrated and organic apple orchards in 1998 and 1999

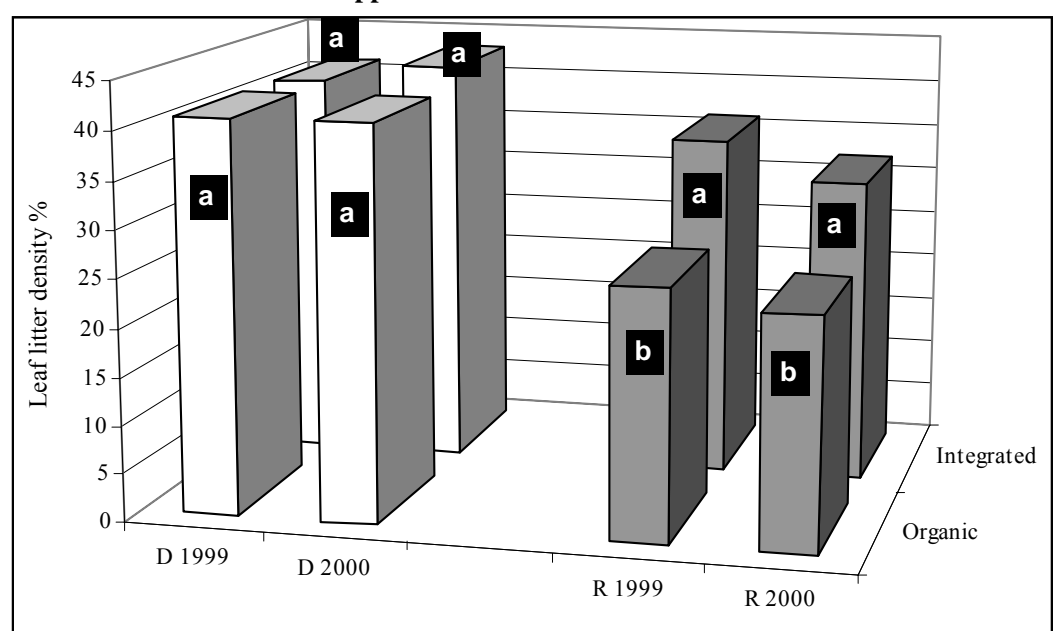

The bold letters on the columns sign the significant differences within the given plant protection system at $\mathrm{P}<0.05$.

$\mathrm{D}=$ Debrecen, Hungary; $\mathrm{R}=$ Randwijk, The Netherlands.

Figure 5: Potential ascospore dose (estimated production of ascospores per $\mathbf{m}^{2}$ orchard floor) in integrated and organic apple orchards in 1998 and 1999 at bud break

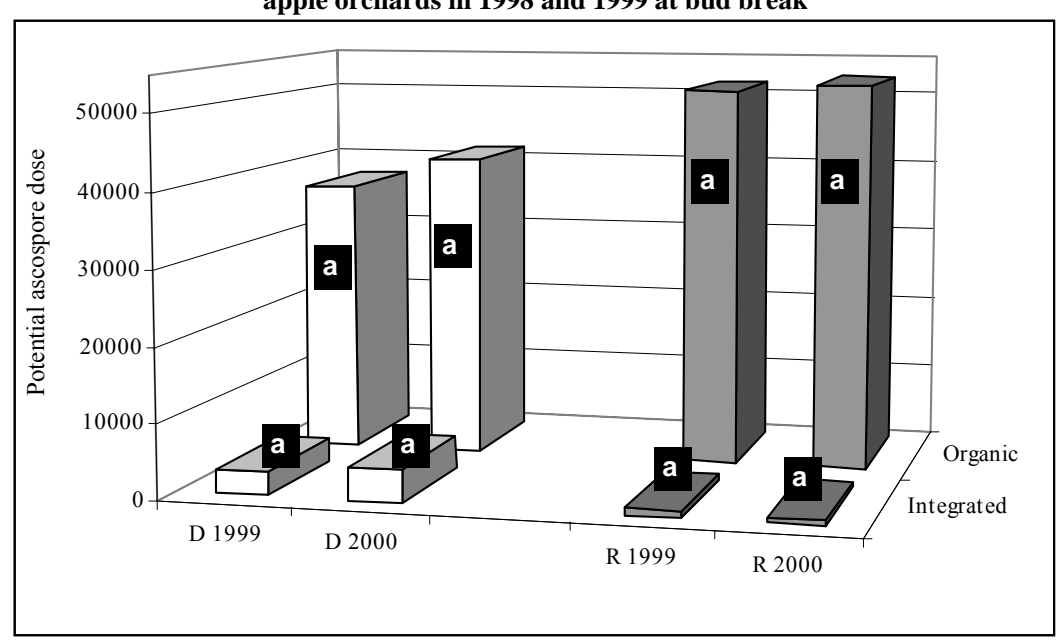

The bold letters on the columns sign the significant differences within the given plant protection system at $\mathrm{P}<0.05$.

$\mathrm{D}=$ Debrecen, Hungary; $\mathrm{R}=$ Randwijk, The Netherlands. 


\section{DISCUSSION}

Determination of potencial ascospore dose showed that primary inoculum accumulated in high amounts in the organic orchards. According to literature data, $\mathrm{PAD}$ values can range between 0 and 1000000 ascopores $/ \mathrm{m}^{2}$ in the orchard floor but the values are highly dependent upon the efficiency of the previous year's plant protection (Gadoury and MacHardy, 1986; Scheer van der, 1993; MacHardy, 1996; Stensvand and Amundsen, 1997).

In this study, PAD values of the integrated orchard at Debrecen-Pallag were medium in 1999 and 2000 (3062 and 4275 ascospores $/ \mathrm{m}^{2}$ ) and low at Randwijk orchard (842 and 673 ascospores $/ \mathrm{m}^{2}$ ). The relatively high PAD values in Hungary were due to the fact that the two orchards (organic and integrated) were close to each other. Moreover, fungicide sprayings in both years were finished by the middle of August. This has also contributed to the increase of inoculum accumulation, which caused a slight autumn epidemic. This late epidemic increased the LD values, which were higher compared to the Dutch integrated orchard. PAD values in the Dutch integrated orchard were remarkably low, in spite of the favourable weather conditions. The possible explanation for this is that orchards were separated by a $6 \mathrm{~m}$ wide bitumin road and 2 rows of Alnus cordata hedge. In addition, sprayings were performed by precision techniques and applications were not finished until the end of September. Probably, these were the main reasons for the low PAD values, although weather conditions were favourable.

In the organic orchards PAD values were remarkably high in both countries. PAD values of Dutch organic orchards were similar to those of in Hungary, although conditions were different in the two countries. The effect of different conditions can be seen in the differences of LD and LLD values. Lesion density (LD) was approximately twice higher in the Dutch organic orchard than in the Hungarian one (Figure 3). The reason for this was probably the fact that at Debrecen-Pallag $60 \%$ of the cultivars were resistant or tolerant against apple scab, while in the Netherlands a moderately (Schone van Boscoop) and a highly susceptible cultivar (Jonagold) served as the bases of calculation. At the same time, Dutch LLD values in the organic orchard were just the half of those in the organic orchard of Debrecen. This was probably due to the better mineralisation conditions (winter and early spring are more mild and rainy in the middle parts of the Netherlands than in EasternHungary). Summing up, Dutch LD values are two times higher, while Dutch LLD values are two times smaller than those of Hungary. As a consequence, PAD values are approximately equal, despite the different growing and ecological conditions of the two countries.

It can be stated that the PAD method demonstrates the large differences between the integrated and organic orchards as regards the amount of primary inoculum. The integrated way of disease control is effective and ensures low level of fruit damage. In agreement with MacHardy et al. (1993), omitting sprayings at the beginning of the season might be a good strategy for saving cost in integrated orchards if PAD values are lower than 600 ascospores $/ \mathrm{m}^{2}$. However, results have verified that the accumulation of primary scab inoculum is extremely high in the organic orchards. This result was verified by the disease management evaluation method of MacHardy and Sutton (1997). As a consequence, these orchards are very much exposed to high disease pressure because of the limited tools of protection against apple scab. All this indicates that the reduction of primary inoculum sources could have a decisive role in the improvement of apple scab protection's effectiveness.

\section{Acknowledgements}

Thanks are due to the staff of University of Debrecen, Centre of Agricultural Sciences, Department of Horticulture and the staff of the Wageningen University, Institute of Applied Plant Research for their financial support of the work carried out.

\section{REFERENCES}

Anonymous (1995): Az integrált gyümölcstermesztés nemzeti irányelvei. 233-267. In: Inántsy F. (eds.): Az integrált almatermesztés gyakorlati kézikönyve. Gyümölcs- és Dísznövénytermesztési Kutató Fejlesztõ Intézeti Rt. Állomása, Újfehértó

Anonymous (1997): Biotermékek előállításának és minősítésének feltételrendszere. Biokultúra Egyesület, Budapest

Gadoury, D. M.-MacHardy, W. E. (1982): Preparation and interpretation of squash mounts of pseudothecia of Venturia inaequalis. Phytopathology, 72. 92-95.

Gadoury, D. M.-MacHardy, W. E. (1983): A 7-day recording volumetric spore trap. Phytopathology, 73. 1526-1531.

Gadoury, D. M.-MacHardy, W. E. (1986): Forecasting ascospore dose of Venturia inaequalis in commercial apple orchards. Phytopathology, 76. 112-118.

Hirst, J. M. (1952): An automatic volumetric spore trap. Annals of
Applied Biology, 39. 257-265.

MacHardy, W. E. (1996): Apple scab, biology, epidemiology and management. APS Press, St. Paul, Minnesota, USA

MacHardy, W. E.-Gadoury, D. M.-Rosenberger, D. A. (1993): Delaying the onset of fungicide programs for control of apple scab in orchards of low potential ascospore dose of Venturia inaequalis. Plant disease, 77. 372-375.

MacHardy, W. E.-Jeger, M. J. (1983): Integrating control measures for the management of primary apple scab, Venturia inaequalis (Cke.) Wint. Protection Ecology, 5. 103-125.

MacHardy, W. E.-Sutton, D. K. (1997): Autumn scab development: a crucial but poorly understood phase of apple scab epidemiology. Proceedings of $4^{\text {th }}$ workshop on integrated control of pome fruit diseases, 19-23 August 1996, Croydon, England. IOBC/WPRS Bulletin, Bulletin OILB/SROP 20. 9. 163-168. 
Mills, W. D.-LaPlante, A. A. (1951): Diseases and insects in the orchard. Cornell Univ. Ext. Bull., 711. 1-5.

Rossi, V.-Ponti, I.-Marinelli, M.-Giosuè, S.-Bugiani, R. (2000): A new model estimating the seasonal pattern of air-borne ascospore of Venturia inaequalis in relation to weather condition. Journal of Plant Pathology, 82. 2. 134-138.

Sallai, P. (1985): Kiegészítések a magyar kiadáshoz: Az „Ellenőrző műszerek és az előrejelzés” c. fejezethez. 122-123. In: Oberhofer, H. (eds.): Der Apfelshorf Lebensweise und Bekämpfung ( $\mathrm{Az}$ almafavarasodás biológiája és a védekezés). A dél-tiroli gyümölcs- és szőlötermesztési tanácsadókör, Lena, Budapest

Scheer, van der H. A. Th. (1993): forecasting ascospore dose of
Venturia inaequalis as an aid to control of primary scab in commercial orchards. Acta Horticulturae, 347. 127-131.

Seem, R. C. (1986): Methodological comparison of three apple scab simulators. Acta Horticulturae, 184. 33-40.

Stensvand, A.-Amundsen, T. (1997): Investigations on the potential ascospore dose of Venturia inaequalis in Norwegian apple orchards. Proceedings of $4^{\text {th }}$ workshop on integrated control of pome fruit diseases, 19-23 August 1996, Croydon, England. IOBC/WPRS Bulletin, Bulletin OILB/SROP 20. 9. 209-216.

Surján, J. (1974): Az almafa-varasodás. 241-247. In: Benedek, P.Surján, J.-Fésűs, I. (eds.): Növényvédelmi elörejelzés. Mezõgazdasági Kiadó, Budapest 